\title{
Distribution of Individuals and Captures in an Island Population of the Bank Vole ${ }^{1}$
}

\author{
Gabriela BUJALSKA \& Dorota MIESZKOWSKA
}

\begin{abstract}
Bujalska G. \& Mieszkowska D., 1984: Distribution of individuals and captures in an island population of the bank vole. Acta theriol., 29, 11: 147-158 [With 4 Tables \& 3 Figs.]

Estimates of numbers were made five times a year over the period from 1975-1980 in a population of Clethrionomys glareolus (Schreber, 1780) living on Crabapple Island in northeastern Poland, using the CMR method. Parallel to the above the standing crops of herb biomass vere estimated in four forest associations covering the island. A total of 1812 individuals and 22,959 captures were recorded. It was found that fluctuations in the number of individuals and their captures coincide in all the associations, whereas the latter differ in respect of the average number of individuals recorded there and the number of their captures. The largest number of individuals was found in the camp and highly productive herb layer Circaeo-Alnetum and the smallest in the Tilio-Carpinetum typicum association situated on the highest and dryest ground. The largest number of captures was obtained in Circaeo-Alnetum and Tilio-Carpinetum stachyetosum silvaticae associations. The pictures obtained for the different categories of individuals (males, females and among them mature and immature animals) differed, which points to their different habitat requirements. A proportionate increase in the number of captures does not always accompany increase in the number of individuals of a given category: in some associations in which, although a large number of individuals of the given category is observed, the number of captures is small, and vice versa. This indicates that the term habitat optimum can be taken to mean several things. A discussion is given of the importance of determining the habitat requirements of different elements of popopulation structure in order to define their role in the ecosystem. Attention was also given to the methodical aspect, connected with estimate of numbers by means of snap-traps or the use of the trap-nights index.

[Institute of Ecology, Polish Acad. Sci., Dziekanów, 05-092 Łomianki, Poland]
\end{abstract}

\section{INTRODUCTION}

The spatial distribution of rodent populations in their habitats has of late aroused increasingly great interest among ecologists (e.g. Zejda, 1976, 1981; Healing et al., 1983; Pucek, 1983). It would appear particularly important to determine which habitat elements play a decisive part in the way in which individuals are distributed, whether all categories of individuals have similar "requirements" and whether the character of distribution changes together with variations in population numbers. This group of problems is directly connected with the rapidly developing

${ }^{1}$ Praca wykonana w ramach problemu MR. II.15 koordynowanego przez Instytut Ekologii PAN. 
studies on the role of rodents in the ecosystem (Grodziński \& Petrusewicz 1983).

Studies on population distribution are generally limited to examining the distribution of individuals, whereas distribution of captures may also point to the way in which use is made of space. Bock (1972) drew attention to this when she studied exploitation of different habitats by a population of Clethrionomys glareolus in four forest associations on Crabapple Island.

Among the studies continued on this island an attempt has been made to analyze distribution (understood here as "micro-distribution" (Southern, 1979) of chosen categories of individuals and their captures in several forest associations.

\section{AREA, MATERIAL AND METHODS}

The studies were carried out from 1975-1980 on Crabapple Island in Lake Beldany in northeastern Poland. 4 ha of the island is covered by forest associations in which Traczyk (1965) distinguished: Salici-Franguletum Malc., 1929 (SF), CircaeoAlnetum Oberdorfer, 1953 (CA) and Tilio-Carpinetum Traczyk, 1962 (TC) in two sub-associations - T.-C. stachyetosum silvaticae (TCS) and T.-C. typicum (TCT) (Fig. 1). The distribution of these associations is clearly connected with the contours

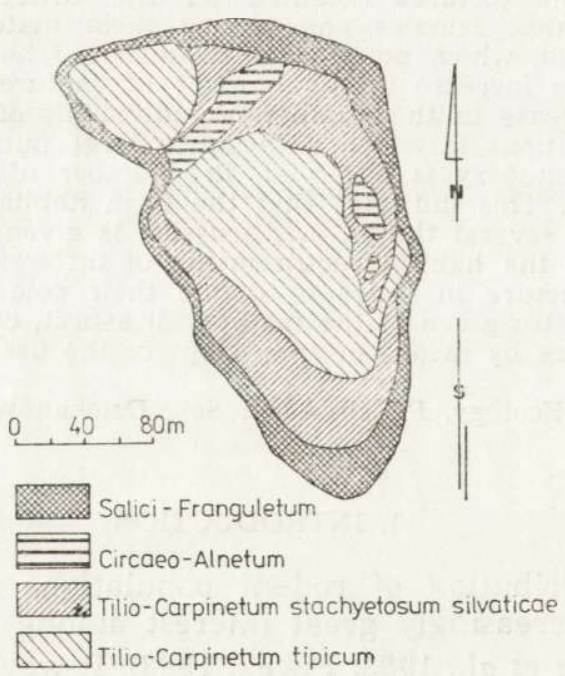

Fig. 1. Distribution of forest associations on the island in Lake Beldany.

of the area and the action of lake water. The low and frequently flooded banks of the island are covered by SF, which occupies about 15 per cent of its area. Salix cinerea occurs almost on its own in the compact bush layer and Carex acutiformis in the herb layer. The depressions in the area into which subsoil water is observed to seep is covered by CA, which occupies 7 per cent of the island's surface. This association is best formed in the depression running across the island. Alnus glutinosa dominates here in the tree layer, there are few bushes and the abundant herb layer is characterized by Chrysosplenium alterni- 
folium, Circaea alpina and Cirsium oleraceum. The remaining part of the island, higher and far dryer, is covered by TC. Pinus silvestris, Tilia cordata and Carpinus betulus occur in the tree layer of the two sub-associations. The tree stand TCS avellana dominates in the bush layer of TCS and TCT. The herb layer of TC is distinguished by an admixture of Alnus glutionsa and Ulmus scabra. Corylus is less dense that of SF and CA, but the species composition is more diversified. A detailed description of the plant associations is to be found in papers by Traczyk $(1965,1971)$.

A grid of 159 trapping sites was distributed evenly over the island, with intervals of $15 \mathrm{~m}$ between rows and lines. Three live-traps baited with oats were placed on each trapping site.

Every year from April to October 5 censuses were made at 6 -week intervals. The census lasted 7 days, and the traps were inspected twice daily (at 7.00 and 19.00). The CMR method was employed and the individuals were marked individually with numbers by toe-clipping. The position (scrotal and abdominal) of the testes was estimated in males, this forming the basis for distinguishing sexually mature and immature animals. Vaginal smears were taken from females, and their analysis made it possible to distinguish between immature and mature females, including gestating females among the latter (Bujalska, 1970). The numbers of rodents was estimated by the "general census" method. A detailed description of the way in which material was collected is to be found in the paper by Crliwicz et al. (1968).

Parallel to estimates of the numbers of rodents, estimates were made 5 times during the course of the year of the standing crop of the forest herb layer biomass forming the potential food of the bank vole (Obrtel \& Holišova, 1974; Gębczyńska, 1983). Stratified random sampling was applied. Samples were taken from 20 plots of $0.1 \mathrm{~m}^{2}$ in each of the associations distinguished. All the aerial parts of plants from the herb layer were collected, dried and weighed (Bujalska, 1984).

The distribution of the categories of individuals distinguished and their captures were analyzed in each of the four forest associations in successive censuses, since comparison of the relations between distribution of individuals and their captures permits of a better assessment of the behaviour of these individuals in time and space.

On account of the different size of areas covered by these associations (Fig. 1) the number of individuals and their captures in each of them was expressed in the form of indices of the number of animals or captures per unit of space. This unit was the trapping site, which was taken to represent an optionally chosen place in space within the area of the given association. The basis for calculations consisted of the number of individuals and their captures effected in a given plant association, regardless of whether the given individual was also recorded in other associations. A total of 1812 individuals was obtained, with a joint total of 22,959 captures.

Comparison of coincidence of fluctuations in the categories of individuals distinguished or their captures in the four associations was examined by means of Kendall's concordance index (W) (Siegel, 1956). Differences in the mean value of the number of individuals or captures in these habitats was estimated by means of the two-way Friedman's anova by ranks $\left(X_{r}^{2}\right)$ Siegel, 1956). In the presence of significant differences (revealed by the two-way anova) the Wilcoxon's matched-pairs signed-ranks $T$ test was used to determine which pairs of associations show significant differences in the mean values. Use was also made of analysis of regression ccefficients of the index of number of captures in relations to the index for number of individuals. 


\section{RESULTS}

Changes in population numbers in the years covered by the present studies were characterized by typical seasonal variations (Fig. 2). Peak population numbers did not exceed 284 individuals and were thus lower than those observed in 1966 and 1968 (respectively 306 and 383 individuals) (Bujalska, 1970). As in previous years stabilization in the num-

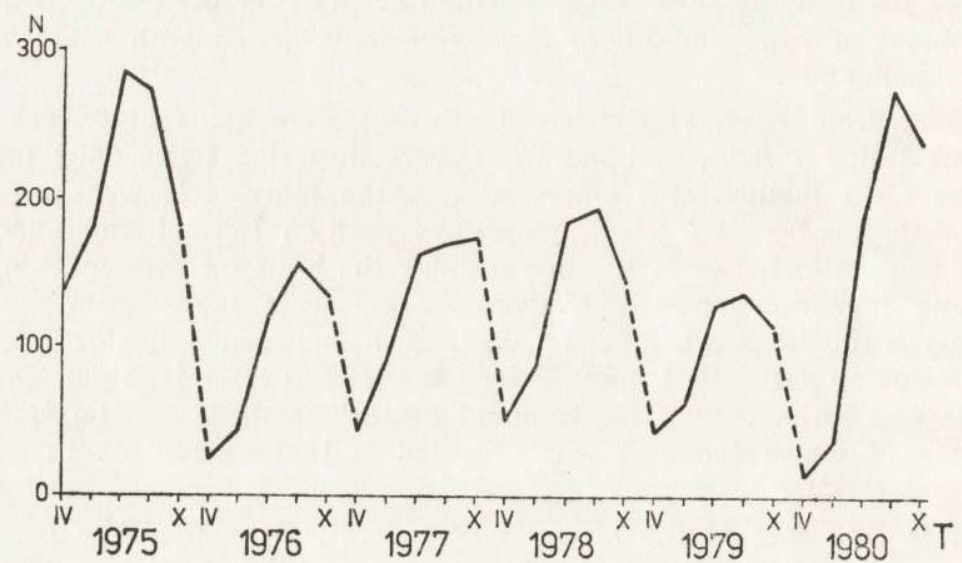

Fig. 2. Dynamics of population numbers.

Table 1

Description of the significance of differences in the distribution of selected categories of individuals and their captures in four forest associations.

\begin{tabular}{lcccc}
\hline & $\begin{array}{c}W, \text { Kendall's coeff. of } \\
\text { concordance (changes in time) }\end{array}$ & $\begin{array}{c}X_{r}^{2} \text {, Friedmann's test } \\
\text { (changes in space) }\end{array}$ \\
\hline Individuals & & & & \\
Males \& females & 0.906 & $p<0.001$ & 72.29 & $p<0.001$ \\
Adult females & 0.861 & $p<0.001$ & 9.57 & $p<0.025$ \\
Pregnant females & 0.769 & $p<0.001$ & 20.66 & $p<0.001$ \\
Immature females & 0.842 & $p<0.001$ & 7.95 & $p<0.05$ \\
Adult males & 0.739 & $p<0.001$ & 39.95 & $p<0.001$ \\
Immature males & 0.845 & $p<0.001$ & 13.16 & $p<0.02$ \\
$\quad$ Catches & & & & \\
Males \& females & 0.863 & $p<0.001$ & 9.36 & $p<0.05$ \\
Pregnant females & 0.668 & $p<0.001$ & 3.061 & $p>0.30$ \\
Adult females & 0.772 & $p<0.001$ & $3.22^{1}$ & $p>0.30$ \\
Immature females & 0.853 & $p<0.001$ & 7.53 & $p \approx 0.05$ \\
Adult males & 0.549 & $p<0.001$ & 0.571 & $p>0.9$ \\
Immature males & 0.863 & $p<0.001$ & 18.44 & $p<0.001$ \\
\hline
\end{tabular}

1 Differences are not significant in mean values.

ver of mature individuals (Bujalska, 1970, 1973) and inhibition of the e of sexual maturation were observed (Bujalska, 1984), hence the her of sexually immature individuals was most variable. 
A check was made to see whether the directions taken by fluctuation in the number of individuals belonging to the categories distinguished are similar in successive censuses in all four forest associations. A significant concordance in time of these fluctuations was found (Table 1). A similar picture was obtained when analyzing fluctuations in the number of captures (Table 1).

Examination was next made to see whether there are differences between the mean numbers of the categories of rodents distinguished in different habitats. These values differ significantly in all the categories of individuals analyzed (Table 1). A similar analysis made for the number of captures points to the existence of differences in the mean values in the category of all males and females. This is due to significant differences in mean values of captures in the juvenile male category and similar tendencies in the juvenile female category (Table 1).

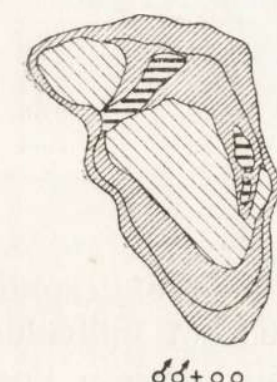

$868++9+$

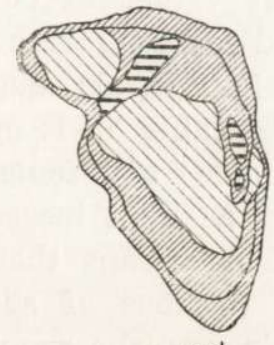

$\varsubsetneqq$ ad

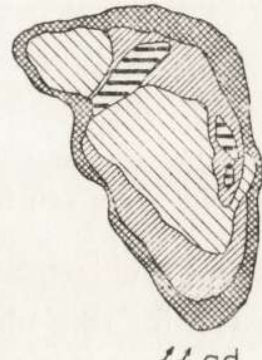

bo ad.

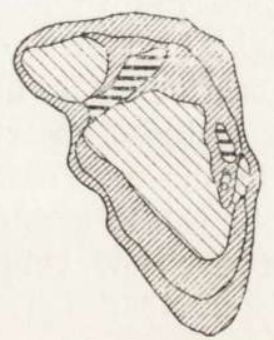

¡q pregnant
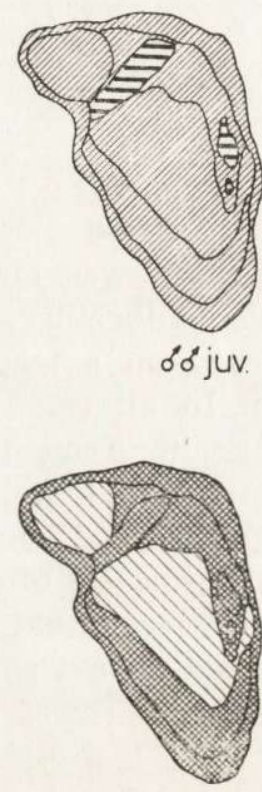

q̊ juv.

Fig. 3. Description of the distribution of selected categories of individuals in four forest associations.

Individuals in almost all categories (with the exception of juvenile females) prefer $\mathrm{CA}$, and occur least numerously (with the exception of juv. males) in TCT. TCS associations are intermediate in this respect since all categories of individuals (except for juv. females) occur in average numbers and SF, in which only adult males in juv. females occur numerously (Fig. 3). It is possible in this way to arrange the associations in decreasing order to the number of individuals registered 
in them: $\mathrm{CA} \rightarrow \mathrm{SF} \rightarrow \mathrm{TCS} \rightarrow \mathrm{TCT}$. In this order it is difficult to find the rank of asociations with intermediate numbers of individuals registered in them, that is, SF and TCS.

All males and females produced greatest numbers in CA and TCS and smaller numbers in SF and TCT (Table 2). The distribution of captures of juvenile males primarily affected distribution of captures of the whole population: the most numerous captures of these animals were found in CA, slightly fewer in TCT and TCS and fewest in SF. Mean values of captures per trapping site are given in Table 2; results of statistical analysis in Table 1.

Table 2

Mean number of captures of individuals in categories distinguished per trapping site per census in different forest association.

\begin{tabular}{ccccccc}
\hline Association $^{1}$ & M \& F & Ad. F & Pregn. F & Immat. F & Ad. M & Immat. M \\
\hline TCT & 4.69 & 1.75 & 0.71 & 0.59 & 1.32 & 1.02 \\
TCS & 5.26 & 2.01 & 0.80 & 0.84 & 1.46 & 0.94 \\
SF & 4.23 & 1.59 & 0.63 & 0.65 & 1.36 & 0.66 \\
CA & 5.55 & 1.88 & 0.75 & 0.89 & 1.49 & 1.34 \\
\hline
\end{tabular}

${ }_{1}$ Full names of the forest associations are given in the text.

A check was made to ascertain whether the number of captures increases together with increase in the mean number of individuals recorded on a trapping site. The regressions calculated took a linear form. In all cases correlations and coefficients $b$ of regression were significant. Tendency was observed to attain highest values of coefficient $b$ for individuals caught in TCT and TCS and lowest for those caught in CA. The values of coefficient $b$ obtained for individuals caught in SF are most often similar to those observed in CA (Table 3). It may be mentioned that increase in the number of adult males and females recorded on a trapping site in $\mathrm{CA}$ is accompanied by a slight increase in the number of their captures (low value of $b$ ). This means that a relatively high (highest among all the associations) number of adult males and females are rarely recaptured in this association. The reverse applies to TCT: here adult individuals (both males and females) are less numerous, but are repeatedly caught.

At the same time, as shown in Fig. 3 , there is a distinct tendency to attain maximum numbers in almost all categories of individuals in association CA and lowest in TCT. This may also be illustrated by analysis of mean values of the number of individuals on a trapping site observed in different associations (Table 4). A statistical measure of differences between mean values has been given above, while the mean values given in Table 3 only confirm the existence of certain tendencies.

Analysis of coefficient $b$ and also of the numbers in the categories of individuals examined in the four forest associations may indicate 
that these individuals make different use of the area, but on one condition only: that the results obtained reflect real (ecological) differences and are not the result of errors in the method. The size of the associations analyzed differs as shown in Fig. 1. The smallest of them is CA, in which maximum number and lowest values of coefficient $b$ were simultaneously observed. It may therefore be supposed that the picture obtained may not necessarily be caused by the different "quality" of this association, but by the increase of the so-called "margin effect" due to

Table 3

Regression of number of captures in relation to number of individuals. For each category of individuals and associations ${ }^{1}$ linear regression coefficients $a$ and $b$ are given and $95 \%$ confidence interval for coefficient $b$, given in brackets, and also value of correlation coefficient.

\begin{tabular}{|c|c|c|c|c|c|}
\hline $\begin{array}{l}\text { Category of } \\
\text { individuals }\end{array}$ & & $\mathrm{TCT}^{1}$ & TCS & SF & $\mathrm{CA}$ \\
\hline $\begin{array}{l}\text { Males \& } \\
\text { females }\end{array}$ & $\begin{array}{l}a \\
b\end{array}$ & $\begin{array}{c}-0.266 \\
4.315 \\
(3.69-4.95) \\
+0.929\end{array}$ & $\begin{array}{c}-0.141 \\
3.651 \\
(3.156-4.146) \\
+0.937\end{array}$ & $\begin{array}{c}-0.209 \\
2.945 \\
(2.478-3.412) \\
+0.917\end{array}$ & $\begin{array}{c}-0.140 \\
2.544 \\
(2.223-2.865) \\
+0.945\end{array}$ \\
\hline Adult & $a$ & $\begin{array}{l}+0.929 \\
-0.194\end{array}$ & $\begin{array}{r}+0.937 \\
0.031\end{array}$ & $\begin{array}{l}+0.917 \\
-0.213\end{array}$ & $\begin{array}{r}+0.945 \\
0.006\end{array}$ \\
\hline ales & $b$ & $\begin{array}{c}5.179 \\
(4.404-5.954)\end{array}$ & $\begin{array}{c}4.182 \\
(3.040-5.324)\end{array}$ & $\begin{array}{c}3.715 \\
(3.202-4.228)\end{array}$ & $\begin{array}{c}2.509 \\
(1.998-3.020)\end{array}$ \\
\hline & $r$ & +0.925 & +0.800 & +0.935 & $\begin{array}{r}+0.873 \\
-0.127\end{array}$ \\
\hline $\begin{array}{l}\text { Preg: } \\
\text { fen }\end{array}$ & $\begin{array}{l}a \\
b\end{array}$ & $\begin{array}{c}0.005 \\
4.991 \\
(4.063-5.919)\end{array}$ & $\begin{array}{c}-0.025 \\
4.725 \\
(3.896-5.554)\end{array}$ & $\begin{array}{c}0.002 \\
3.442 \\
(2.348-4.536)\end{array}$ & $\begin{array}{c}-0.127 \\
3.100 \\
(2.288-3.912)\end{array}$ \\
\hline & $r$ & +0.911 & $\begin{array}{l}+0.920 \\
\end{array}$ & +0.792 & +0.847 \\
\hline Immature & $a$ & 0.009 & -0.136 & 0.113 & -0.013 \\
\hline fer & $b$ & $\begin{array}{c}3.346 \\
(2.639-4.053)\end{array}$ & $\begin{array}{c}3.618 \\
(2.907-4.329)\end{array}$ & $\begin{array}{c}2.299 \\
(1.400-3.198)\end{array}$ & $\begin{array}{c}2.416 \\
(1.948-2.884)\end{array}$ \\
\hline & $r$ & +0.901 & +0.912 & +0.762 & +0.926 \\
\hline Adult & $a$ & -0.095 & 0.089 & -0.162 & 0.235 \\
\hline & $b$ & $\begin{array}{c}4.282 \\
(3.572-4.992)\end{array}$ & $\begin{array}{c}3.219 \\
(2.858-3.580)\end{array}$ & $\begin{array}{c}3.059 \\
(2.473-3.717)\end{array}$ & $\begin{array}{c}1.866 \\
(1.296-2.436)\end{array}$ \\
\hline & & +0.911 & +0.956 & +0.876 & +0.765 \\
\hline Immature & $a$ & -0.035 & -0.083 & 0.140 & -0.272 \\
\hline & $\begin{array}{l}b \\
r\end{array}$ & $\begin{array}{c}3.832 \\
(2.849-4.815) \\
+0.853\end{array}$ & $\begin{array}{c}3.455 \\
(2.633-4.277) \\
+0.874\end{array}$ & $\begin{array}{c}2.037 \\
(1: 552-2.522) \\
+0.889\end{array}$ & $\begin{array}{c}3.194 \\
(2.672-3.716) \\
+0.937\end{array}$ \\
\hline
\end{tabular}

1 Full names of the forest associations are given in the text, p. 148.

the relation of size of association area/size of the animals' home range. Henc it is possible to include in the pool animals caught in CA and also those whose home ranges overlap this association. If this were so in fact, the value of coefficient $b$ would form in accordance with the gradient of association size. Thus arranging them in order of increasing size of CA, SF, TCS, TCT we should obtain increase in $b$ parallel to this. Further it would have to be expected that we should then obtain a similar picture for the categories of individuals with home ranges of similar size such as, e.g. adult females, females juv. and males juv. (Bujalska, 1975; Bujalska, unpubl. data) and different for categories with home ranges of different size (e.g. between the categories of in- 
dividuals given above and adult males, the home ranges of which are several times greater (Bujalska, unpubl. data).

The direction of changes is not, however, consistent, as shown by analysis in Table 3. For instance increase in $b$ in the direction CA $\rightarrow$ TCT in the case of sexually mature females is in proportion to the size of the association, whereas with juvenile females the direction of changes in $b$ is the reverse: it declines together with increase in area size of the habitat. A similarly inconsistent picture is obtained from comparison of $b$ in adult and juv. males.

Table 4

Mean number of individuals in categories distinguished per trapping site per census in different forest associations.

\begin{tabular}{ccccccc}
\hline Association $^{1}$ & M \& F & Ad. F & Pregn. F & Immat. F & Ad. M & Immat. M \\
\hline TCT & 1.147 & 0.375 & 0.176 & 0.251 & 0.331 & 0.353 \\
TCS & 1.369 & 0.499 & 0.217 & 0.370 & 0.426 & 0.397 \\
SF & 1.507 & 0.498 & 0.230 & 0398 & 0.502 & 0.410 \\
CA & 2.236 & 0.723 & 0.345 & 0.638 & 0.671 & 0.687 \\
\hline
\end{tabular}

1 Full names of the forest associations are given in the text.

It may therefore be assumed that the differences observed in use of associations are due to the different requirements of the various categories of individuals and/or different values of the habitats.

Food supply may form one of the measures of the different value of associations. The mean value of herb layer biomass in associations CA, SF', TCS and TCT are respectively: $529,331,380$ and $472 \mathrm{~kg}$ of dry mass/ha. With the exception of the maximum values of biomass in association CA, most numerously inhabited by the rodents, the picture is not what could have been expected. Complete agreement was not obtained either from analysis of the herb biomass in July (considered by phytosociologists as closest to estimated productivity). The gradient of herb layer biomass stated in July in associations CA $\rightarrow$ TCT is as follows: $700,505,421$ and $491 \mathrm{~kg}$ dry mass/ha. When this is compared with the gradient of number of individuals on a trapping site (Table 4) respectively: $2.24,1.51,1.46$ and 1.15 , it can easily be seen that only TCT forms an exception in the sequence of changes: it is characterized by a greater biomass standing crop than TCS and at the same time lower mean value for the number of individuals on a trapping site. It may therefore be assumed that not only the association's food supply is re:sponsible for the way in which the rodents make use of the given habitat.

\section{DISCUSSION}

It would be a truism to state that more numerous (denser) rodent populations are encountered in habitats with more abundant food supply 
and the reverse in poor habitats, nevertheless no objective measure of abundance (quality) of the habitat has yet been suggested for rodents, although attempts have been made at describing habitat values (expressed by index of diversity) for certain Arthropoda (Mühlenberg et al., 1977). In the present study Traczyk's $(1965,1971)$ phytosociological description of forest associations covering the island has been used as a basis. Studies were made by Bock (1972), in accordance with this division, on the way in which associations were used by a population of C. glareolus. In this author's opinion the factor determining the intensivity with which rodents penetrated patches of habitat is humidity: increase in the humidity of the association was accompanied by increase in penetration by rodents. The present studies have shown that one of the factors responsible for increase in the number of individuals recorded in a given habitat may be the abundance of food there. The differences, accompanying population variations found by Bock (1972), however, in the number of individuals visiting different associations must be revised, since this author assumed a proportion between the number of individuals visiting the given habitat and the size of such a habitat.

The results of analysis of regression between the number of different categories of individuals and their captures in four forest associations, pointing to the different way in which these individuals make use of space, are remarkable. Adult females, for instance, were recorded most numerously in Circaeo-Alnetum, but visited this habitat seldom (increase in the number of recorded individuals was accompanied by a slight increase only in the number of their captures). Adult males behave in a similar way. This may mean that this association lies outside the habitat optimum for this category of individuals and that the animals only visit this habitat ("drop in for a minute") e.g. in search of food (since the habitat is characterized by particularly high herb layer production in comparison with the other associations). At the same time individuals belonging to this same category behave differently in TC'T. Although fewer individuals were recorded there per trapping site, they were characterized by a high number of captures (they "resided" there). The total number of individuals recorded in a habitat of their captures cannot provide evidence of the variety of attractions of a habitat to rodents, but only of the character of the relation between two parameters pointing to the way in which use is made of the space. It may be expected that a habitat which is optimum from one aspect may not necessarily be equally optimum from another aspect (Grüm, 1965, 1971) and what is more, these optima may take a different form for different elements of population structure.

The question remains open as to whether the differences observed are due to free choice of a given habitat or take place under pressure 
from adult individuals. It is only analysis of habitat values carried out from the angle of the capacity for satisfying different vital requirements of different categories of individuals which can give a reply to this, and it will form the subject of subsequent studies.

The present results also point to the methodical aspect on which inadequacy of distribution of different categories of the animals and their captures may exert an influence. This may lead to different degrees of accuracy in estimates of their numbers, which is not taken into consideration when analysing results obtained using snap-traps or when using the "trap-night" index. In addition the question as to whether a large number of individuals may occur in a given part of the ecosystem, but remain there a short time only, or vice versa, there are few animals but they live there permanently, is of prime importance in determining the ecological role of a rodent population or given elements of its structure, in the ecosystem.

\section{REFERENCES}

2. Bock E., 1972: Use of forest associations by bank vole population. Acta theriol., 17: 203-219.

2. Bujalska G., 1970: Reproduction stabilizing elements in an island population of Clethrionomys glareolus (Schreber, 1780). Acta theriol., 15: 381-412.

3. Bujalska G., 1973: The role of spacing behaviour among females in the regulation of the reproduction in the bank vole. J. Reprod. Fert., Suppl., 19: $463-472$.

4. Bujalska G., 1975: The effect of supplementary food on some parameters in an island population of Clethrionomys glareolus (Schreber, 1780). Bull. Acad. nol. Sci., Cl. II, 23: 23-28.

5. Bujalska G., 1984: Population dynamics of an island population of Clethrionomys glareolus (Schreber, 1780). Acta Zool. Fenn.

6. Gębczyńska Z., 1983: Feeding habits. [In: "Ecology of the bank vole", ed. K. Petrusewicz]. Acta theriol., 28, Suppl. 1: 40-49.

7. Gliwicz J., Andrzejewski R., Bujalska G., \& Petrusewicz K., 1968: Productivity investigation of an island population of Clethrionomys glareolus (Schreber, 1780). I. Dynamics of cohorts. Acta theriol., 13: 401-413.

8. Grodziński W., \& Petrusewicz K., 1983: Contribution to the functioning of forest ecosystems. [In: "Ecology of the bank vole", ed. K. Petrusewicz]. Acta theriol., 28, suppl. 1: 207-213.

9. Grüm L., 1965: The significance of the migration rate in the regulation of intensity of penetration of the habitat by populations of two species of the Carabidae. Ekol. pol. A, 13: 575-591.

10. Grüm L., 1971: Spatial differentiation of the Carabus L. (Carabidae, Coleoptera) mobility. Ekol, pol., 19: 1-34.

11. Healing T. D., Jewell V. T., Jewell P. A., Rowlands J. W. \& Gipps J. H. W., 1983: Populations of the bank vole (Clethrionomys glareolus) and long-tailed mouse (Apodemus sylvaticus) on Skomer Island, Dyfed. J. Zool., Lond., 199: $447-460$.

12. Mühlenberg M., Leipold D., Mader H. J., \& Steinhauer B., 1977: Island ecology of Arthropods. I. Diversity, niches and resources on some Seychelles Islands. Oecologia (Berl.), 29: 117-134. 
13. Obrtel R. \& Holišova V., 1974: Trophic niches of Apodemus flavicollis and Clethrionomys glareolus in a lowland forest. Acta Sc. Nat. Brno, 8: 1-37.

14. Pucek M., 1983: Habitat preference. [In: "Ecology of the bank vole", ed. K. Petrusewicz). Acta theriol., 28, Suppl. 1: 31-40.

15. Siegel E., 1956: Nonparametric statistics for the behavioral sciences. McGrawHill International Book Company: 1-312 Auckland.

16. Southern H. N., 1979: Population processes in small mammals. [In: "Ecology of small mammals", ed. D. M. Stoddart]. Chapman and Hall: 63-101 London.

17. Traczyk H., 1965: Roślinność "Wyspy Dzikiej Jabłoni” na Jeziorze Bełdańskim. Fragm. florist. et geobot., 11: $541-545$.

18. Traczyk H., 1971: Relation between productivity and structure of the herb layer in associations on "The Wild Apple-Tree Island" (Masurian Lake district). Ekol. pol., 19: 333-363.

19. Zejda J., 1976: The small mammal community of a lowland forest. Acta Sc. Nat., Brno, 10: 1-39.

20. Zejda J., 1981: The small mammal community of a spruce monoculture. Acta Sc. Nat., Brno, 15: 3-31.

Accepted, March 2, 1984.

Gabriela BUJALSKA i Dorota MIESZKOWSKA

ROZMIESZCZENIE OSOBNIKOW I ZEOWIEN W WYSPOWEJ POPULACJI NORNICY RUDEJ

\section{Streszczenie}

Badania prowadzono na 4 ha wyspie Dzikiej Jabłoni na jez. Beldany w latach 1975-1980. W każdym roku, stosując metodę CMR, dokonywano pięciokrotnie oceny liczebności gryzoni oraz stanów biomasy runa leśnego. Dysponowano liczba 1812 osobników o łącznej liczbie 22959 złowień. Wyróżniono pięć kategorii osobników: samce, samice a wśród nich dojrzale, ciężarne i niedojrzałe płciowo.

Analizowano rozmieszczenie osobników i ich zlowień względem wyróżnionych wcześniej zbiorowisk leśnych (Traczyk, 1965, 1971) (Ryc. 1). Ze względu na różną wielkość płatów zbiorowisk, liczbę osobników bądź złowień wyrażano w postaci wskaźników liczby osobników (złowień) na jednostkę przestrzeni (punkt połowu). Analizy statystycznej dokonywano stosując testy nieparametryczne.

Obserwowana liczebność populacji nornicy rudej niższa była niż w latach 1966--1970 (Ryc. 2). Podobnie jednak jak w latach ubieglych obserwowano stabilizację liczby dojrzałych samic.

Kierunki zmian liczby osobników i złowień były podobne w kolejnych seriach połowów we wszystkich zbiorowiskach leśnych, natomiast różne były ich wartości przeciętne (Tabela 1). Osobniki należące do prawie wszystkich kategorii występowały najliczniej w wilgotnym i obfitym w runo Circaeo-Alnetum, a najmniej licznie w suchym Tilio-Carpinetum typicum (Ryc. 3). Złowienia najliczniej realizowane były w Circaeo-Alnetum $i$ Tilio-Carpinetum stachyetosum silvaticae a mniej liczne w Salici-Franguletum i Tilio-Carpinetum typicum (Tabela 2).

Wzrostowi liczby danej kategorii osobników zarejestrowanych w danym zbiorowisku nie zawsze towarzyszył proporcjonalny wzrost liczby złowień, przy czym osobniki należące do analizowanych kategorii zachowywaly się różnie w różnych zbiorowiskach (Tabele 2, 3, 4). 
$\mathrm{Na}$ uwagę zasługuje różne zachowanie się dojrzałych samców i samic w Circaeo-Alnetum i Tilio-Carpinetum typicum. Osobniki te występowały licznie w pierwszym z tych zbiorowisk, lowiły się tam jednak rzadko, podczas gdy w drugim - odwrotnie: występowały mniej licznie, charakteryzowały się jednak wyższą łownością. Wskazuje to na wieloznaczność pojęcia optimum środowiskowego.

Fakt różnego sposobu wykorzystania zbiorowisk przez różne składowe struktury pepulacji wydaje się mieć znaczenie przy określaniu roli, jaką pelnią one w ekosystemie. Powinien być również uwzględniony przy szacowaniu liczebności i składowych jej struktury. 